\title{
Canibalismo y sacrificio en las dulces tierras del azúcar
}

Alejandro Isla P. $^{1}$

\author{
En memoria de mi compañero y amigo \\ José Ignacio Barroso
}

\section{RESUMEN}

El artículo analiza la importancia de los mitos asociados al canibalismo dentro de la cultura popular del Noroeste argentino, en especial del mito del Perro Familiar en los trabajadores vinculados a los ingenios azucareros. Se muestra la relevancia de distintas interpretaciones de los mitos, que representan diversas apropiaciones simbólicas de las relaciones sociales de poder que constituyeron la base de la explotación azucarera. Por ende, se trata de una coproducción del mito en la que participan tanto los sectores hegemónicos como los subalternos.

\section{ABSTRACT}

The article analyzes the importance of the myths related to cannibalism within the folk culture of Argentina's Northwest, particulary the Family Dog myth among the workers of sugar cane works. The relevance of different interpretations of myth is shown, wich represent various symbolic appropiations of power social relationships, wich constituted the basis of sugar explotation. Therefore, it is a co-production of the myth, in wich both the hegemonic and subject sectors are involved.

\section{Introducción}

En este trabajo quiero destacar que el canibalismo

\footnotetext{
1 Investigador de CONICET-FLACSO. Email: aleisla@mail.retiva.ar

Este artículo es parte de un libro que estoy finalizando. La investigación arrancó a principios de los ' 90 con el financiamiento de la National Science Foundation (bajo la coordinación de Selby), del National Endowment for Humanities (bajo la coordinación de Julie Taylor) y en particular del CONICET- Argentina.

2 NOA: Noroeste argentino, compuesto de las provincias de Jujuy, Salta, Tucumán, Catamarca, Santiago del Estero y La Rioja.
}

está en la base de la interpretación popular de la "riqueza de los patrones del azúcar" y constituye un elemento central de la cultura política del NOA. ${ }^{2}$ Allí se denuncian "desapariciones" de personas como hechos corrientes del funcionamiento de ingenios y plantaciones, que a su vez, anuncian diferentes tipos de desapariciones. Esta relación entre "anunciar" y "denunciar" marca uno de los ejes de tensión en el amplio grupo de versiones que constituyen El Familiar. Se vincula con la conciencia social histórica y mítica que tienen los pobladores, con su idea de sacrificio; y a las luchas sociales, pero también simbólicas, por el sentido del mito: unos pensando en el inexorable sacrificio de vidas humanas, que se debe hacer para que la maquinaria se mueva, dé trabajo, produzca; y otros denunciando la fetichización implícita en el mensaje. Por lo tanto, tratando de demostrar su carácter de superchería, ya que para los pobladores era la patronal quien lo inventó, y sus secuaces quienes ejecutaban las "desapariciones".

El conjunto de versiones sobre El Familiar, esparcidas profusamente por las provincias del NOA, compone un mito muy complejo que lleva a diferentes territorios. La implantación del terror, el disciplinamiento obrero, la explicación del origen de la riqueza, las relaciones de género, son algunos de los sentidos del relato que iré tratando. Por otra parte, si bien la mayoría de las versiones del mito está vinculada a la industria azucarera, el mito del Perro $^{3}$ Familiar es usado en el discurso ordinario

\footnotetext{
3 El diablo puede aparecer de muchas formas animales o humanas, pero la de 'perro' es la más frecuente en versiones recogidas, como en fuentes secundarias. En las tradiciones andinas los "perros negros" puede ser animales peligrosos y guardianes del "país de los muertos" (Zuidema 1980: 35 y 47). También en la conquista y durante la colonia se usaron perros sanguinarios en toda América (Sánchez Ferlosio 1991: 46-48).
} 
como metáfora de relaciones sociales caracterizadas por fuertes asimetrías de poder y autoridad signadas por la arbitrariedad. De allí que vaya más allá de los confines de las relaciones sociales en la plantación y en el ingenio.

En la mayoría de las versiones se anuncia un pacto demoníaco que, para alimentarlo provoca "desapariciones" de trabajadores. A veces, éstos eran encontrados descuartizados. Sus restos macabros eran atribuidos a un festín diabólico. En la imaginación popular, el hambre del diablo es desmesurada, como el hambre de riqueza de las patronales. Existe una infinidad de relatos de "desaparición" de obreros al caer en los trapiches o en las grandes ollas de azúcar hirvientes. Eran accidentes de trabajo frecuentes en cada zafra, cada año. Estos accidentes son

4 El director de cine Octavio Getino --miembro y fundador del grupo de "Cine Liberación", junto a Solanas-- fue quien compuso la versión más barroca del mito con su film "El Familiar", realizado en 1972 y estrenado en 1974. Varios artículos periodísticos con algún reportaje al director cinematográfico anunciaron el lanzamiento de "El Familiar" en Buenos Aires. En 1973 un comentario en un periódico de esa ciudad, anticipaba el estreno local. Decía que el film mencionaba la "desaparición misteriosa de peones" ...instrumentado primero como terror irracional por los patrones... era un perro negro..., (el autor) dice que se inspiró en una versión de Tobías Rosenberg: ...Zupay, el Diablo, había hecho hace muchos años un pacto de sangre con el Dueño de las Tierras. Este vería aumentar sus ganacias, pero debía proporcionar a cambio, la carne y el alma de sus peones a un personaje nacido de ese pacto, "el Familiar" siempre encamado en formas distintas. Un día el Familiar envía a su Emisario y a tres de sus Angeles Custodios, a una tierra habitada por los Oscuros "hijos del Sol" para ofrecer su protección. La familia de los Oscuros se vio dividida por diversas actitudes: Atahualpa, "la Serpiente" negocia con el Emisario; Tupac, "el Pájaro", lo enfrenta desde las montañas; Pampa, "el Arbol", se replegó hacia el desierto. El Familiar devora a la mujer de Pampa y éste, aconsejado por la Madre de los Oscuros, la Pachamama, decide salir a la búsqueda del culpable de su desgracia, para destruirlo. En la búsqueda deberá reunir a su Sombra y al "Pájaro" y a la "Serpiente", sus hermanos...". (La Opinión 19/8/1973). Trata de ser una alegoría política de los violentos años setenta. El "Sol" por momentos representa elípticamente a Perón, que debe retornar para que renazca el alba. Los Oscuros representan al pueblo, a los peronistas en resistencia; pero también son un ícono de "cabecitas negras". Están los patrones, los administradores de riqueza, capataces, militares, los servicios de inteligencia, los políticos representados como aduladores y mentirosos. Uno de ellos es un "blanqueado"; o sea un Oscuro, que ha traicionado. Aparece la guerrilla rural y urbana, el puerto y la inmigración europea ("los primeros albañiles" y Oscuros por contaminación). También hay una crítiça a la idea del "progreso", ligada al capitalismo. O sea Getino construye una versión donde el mito sirve de denuncia, de explicación, y de herra- generalmente atribuidos al Familiar: "El Familiar se lo llevó", reconocen resignados. El mito está así operando en el presente del narrador como un tropo, interpretando y ficcionalizando hechos cotidianos, y al mismo tiempo, recabando los ecos de episodios pasados.

El tema del pacto demoníaco cruza todas las versiones. ${ }^{4}$ Haber hecho un pacto con el demonio es primero que nada "cuestión de hombres" y, segundo, de "hombres con mucho poder", "con mucha autoridad". De allí que en algunas facetas las imágenes que transitan por las versiones, como sus atributos, despiertan fascinación y seducen con su violencia a posibles víctimas y victimarios. Sus ecos rebalsan lo específico de las relaciones de producción en la industria azucarera, alcanzando a figuras

mienta de liberación. Su película está imbuida por el voluntarismo y las esperanzas de su época. En otro artículo periodístico, "Mito y política en un film de Getino", un reportaje al cineasta concluía con sus palabras: "Es el Patrón?, ¿es el Gobiemo?, ¿un partido político en el Poder? Con toda probabilidad el Familiar es también el Patrón, el Poder, la Autoridad, el Opresor. Pero no solamente eso. Es la imagen misma de la injusticia, el yugo que sienten hace siglos los pueblos de América Latina sobre sus espaldas; es el desequilibrio social, la marginación, el extranjero que impone nuevas formas de vida y destruye criaturas preexistentes" (de L'Observatore Romano cuando la película se exhibió en 1973 en Italia, en un Festival de Jóvenes Realizadores Latinoameriocanos, y reproducido en La Nación 16/7/1974). Mario Roca en el semanario Primera Plana reproduce un relato de un viejo que trabajó en Ingenio Santa Ana de Hileret y al que se le apareció el Familiar "...como un sapo enorme... Así, la dominación capitalista y la antropofagia de un sistema de explotación se ven representados por la fantasía popular que se apoya en la creencia del mítico fauno para explicar la injusticia" (Roca 1972: 50). La nota continuaba con un reportaje del cineasta del que rescato esta interpretación: “...El Familiar” se construye por el protagonista, su imagen real es para unos de un modo y para otros de otro; pero a través de estas parcialidades se va encontrando el verdadero enemigo, que a veces aún está adentro de nosotros mismos, como una red de un sistema diabólico" (Roca 1972: 51; mi énfasis). Otro diario de Buenos Aires (14/7/974) en un artículo anónimo, "Historia de un pacto con el diablo", sostenía. "...la prueba está que cuando se hizo público el proyecto de filmarla en Tucumán. no faltó un diario de la zona, perteneciente a los grupos de poder, de que hablara de que queriamos reflotar malintencionadamente lo que ellos llamaban 'una leyenda negra'. Leyenda que pierde vigor con la llegada del peronismo y la organización sindical a partir de 1945", según palabras de Getino. Agustín Mahieu comentaba en La Opinión: "El Familiar es uno de los films más extraños, fascinantes y críticos sobre la realidad y la raíz mítica de las culturas populares". Concluía que: "Getino agrega una fundamentación histórico-política y etnogrắfica más profunda y provocativa" (Mahieu, 1975: 18) 
políticas y eclesiales, a organismos estatales o paraestatales como la Triple $\mathrm{A}^{5}$ o a generales que condujeron la lucha contra la guerrilla en los años '70, como Vilas ${ }^{6}$ y Bussi. Incluso esta asociación fue explícitamente hecha por un órgano propagandístico de la guerrilla: "con Vilas --decían-- ha vuelto el Perro Familiar".?

El mito entonces no es una estructura fija e inamovible de determinadas relaciones sociales, sino que se contextualiza en los diferentes períodos históri$\cos$, como en las diferentes relaciones sociales y tradiciones culturales que confluyen en la región, adornándolo con sus imágenes, símbolos y acontecimientos particulares. Hay un largo período por ejemplo, donde las versiones coinciden en que el Diablo no come carne humana; conforma su apetito sólo con animales. Este período coincide con grandes logros obreros en Tucumán sobre la patronal y el reconocimiento estatal de sus conquistas. Coincide así con el primer "peronismo" que arranca en 1945/1946, donde por primera vez en la historia argentina, se acepta un sindicato en el azúcar. Existiendo por lo menos cincuenta años de luchas sociales que precedieron tal conquista, acompañadas siempre de represiones feroces.

Pero debo matizar la idea de que el terror nace con la plantación. Se encuentran otras raíces en Tucumán, y estas se pierden en los tiempos de la Colonia: las represiones a los levantamientos Calchaquíes en el siglo XVII, la evangelización; la imposición violenta o paulatina del poder colonial constituyen las principales. Por otro lado, el Diablo desembarca en el Nuevo Mundo con los españoles en el siglo $\mathrm{XVI}^{8}$, y ya entonces colonizaba el imaginario popular, mucho antes del surgimiento de las plantaciones, a mediados del siglo XIX. Sin embargo los mitos y rituales de la colonia que narran disputas, inversión de papeles y jerarquías, y reconciliaciones simbólicas entre vencedores y vencidos, que en muchos lugares de América Latina quedan

5 Alianza Anticomunista Argentina (AAA), organización célebre por sus asesinatos y secuestros. Formada en octubre de 1974, fue dirigida por José López Rega, secretario privado de Perón y luego ministro de Bienestar Social, durante su presidencia y luego en la de Isabel Martínez de Perón.

6 "Vilas visto como el Familiar, dicho por los campesinos tucumanos" (Andersen 1993: 164).

7 Estrella Roja, órgano del Partido Revolucionario de los Trabajadores-Ejército Revolucionario del Pueblo (PRT-ERP), movimiento de izquierda partidario de la guerrilla y la lucha armada formado a mediados de los sesenta en Argentina. Su como evidencia (Wachtel 1976) en el Noroeste argentino se disuelven en las versiones míticas del "Perro Familiar".

Los antropólogos han trabajado con fruición sobre mitos y rituales, recogiéndolos especialmente entre los "pueblos primitivos". En este caso estoy hablando de un relato mítico en una sociedad compleja, en la que la industrialización y la urbanización se desarrollaron raudamente desde fines del XIX, lo cual no quiere decir que la modernidad haya logrado una instalación homogénea y completa. Como se ha demostrado largamente --incluso para la región (Rutledge 1987) --determinadas relaciones sociales precapitalistas, son refuncionalizadas por el capitalismo periférico, operando perfectamente imbricadas y aceitadas. Lo mismo ocurre con muchos elementos de la cultura; algunos quedan perdidos en los tiempos, pero otros resplandecen y se actualizan, en la coyuntura histórica, en la conciencia de los actores. De allí que algunas interpretaciones del mito del "Perro Familiar" se hayan hecho desde una idea moral de la riqueza y pobreza, que proviene de un catolicismo popular y colonial, que impregna el sentido común de los sectores populares que habitan la amplia región del Noroeste argentino.

Los por lo menos 450 años de Colonia han dejado una impronta profunda en la antigua Provincia del Tucumán. No sólo en lo simbólico e imaginario, sino también en algunas formas de relaciones sociales. Relaciones sociales de fuerte asimetría, como el "peonaje por deuda", "hijos de crianza", "criaditos" o "propios" llegan al presente en algunas zonas de la provincia (Isla 1996). El mito expresa esas improntas.

\section{Mito e Historia. Los sentidos del Pacto}

Contrariamente a lo que muchos suponen, con su método estructuralista, Lévi-Strauss reconocía (co-

máximo líder fue Mario Roberto Santucho, muerto por fuerzas de seguridad en Buenos Aires en julio de 1976,cuando se aprontaba a partir al exilio. (véase: Seoane 1992)

8 Un sínodo realizado en 1595 en Tucumán mostraba ya esta preocupación por el diablo: "que ninguna persona baile, dance, taña, ni cante, bailes ni cantos lascivos, ni deshonestos que contienen cosas lascivas y que las introdujo el demonio" (cit. por López Cantos 1992: 76). No es que no hubiera ideas y prácticas morales sobre el "mal" con antelación a Lucifer en las culturas locales, pero eran muy diferentes a las cristianas, al menos en las andinas. 
herente con la lingüística estructural) que

"los símbolos... nunca ofrecen una significación intrínseca. Su sentido sólo puede ser de "posición", $y$ por consiguiente, nunca nos es accesible en los mitos mismos, sino con referencia al contexto etnográfico, es decir a lo que podemos conocer de su género de vida, de las técnicas, de los ritos y de la organización social de las sociedades cuyos mitos queremos analizar" (Lévi-Strauss et al, 1967: 127).

Esta importante premisa nos lleva a varias consideraciones. En primer lugar, a la necesidad de buscar en otros campos las precisiones sobre el sentido de uno o más símbolos. El eminente etnólogo a veces denominó a esto la réplica en otras estructuras, que no fueran las míticas; llegando en algunos textos a hablar de homologías, isomorfismo, etc. En segundo lugar, a reconocer la existencia de un nivel oculto o no-consciente para la sociedad en cuestión, el nivel de la estructura, que una vez develado, explicaría el sentido del mito. Esa estructura, como sabemos, tenía más de sincronía, que de diacronía; por lo que ese sentido tendía --en su interpretación-- a ser impermeable a la temporalidad, y, por lo tanto, estable.

En su polémica con el grupo de hermeneutas de Ricoeur, Lévi-Strauss sostuvo que

"las profundas certidumbres (desde el punto de vista nativo sobre las esperanzas o el "mensaje" que un mito determinado realiza) se encuentran en todos los que interiorizan sus propios mitos, pero no pueden ser percibidas y deben ser dejadas de lado por quienes las estudian desde afuera" (Lévi-Strauss et al. 1967: 163).

Este precepto metodológico, enfáticamente enunciado, nos sitúa en una posición incómoda con relación al análisis de estos materiales, pues debemos dejar de lado el o los sentidos explícitos que los emisores --que yo llamaría actores-- dan a estos materiales discursivos. Con esto quiero resaltar que, además de los sentidos ocultos, que como autores debemos revelar, existen sentidos explícitos para los actores, que indispensablemente deben ser tomados en cuenta para la interpretación del relato.

Además estas interpretaciones, siempre heterogéneas, como el corpus mismo, son indispensables para entender la historicidad del relato, su vincula- ción con otros campos, como con la subjetividad del informante. O sea se corporizan, encarnándose en la subjetividad del narrador en la situación de narración. Lévi-Strauss fue muy explícito en el tema, dijo:

"puesto que... estamos prisioneros de la subjetividad, no podemos a la vez, tratar de comprender las cosas desde afuera y desde adentro; no podemos comprenderlas desde adentro más que cuando hemos nacido adentro, cuando estamos efectivamente adentro" (Lévi-Strauss et al, 1967: 166).

En mi enfoque partiré de una premisa radicalmente opuesta, a saber: no podemos comprender los sentidos de un mito (especialmente, qué quiere decir para su sociedad) si no lo analizamos desde adentro y desde afuera. O sea, también desde el significado para los propios nativos. Desde ese significado me propongo analizar los objetivos, los mensajes explícitos del mito, más que su código.

Lévi-Strauss agregaba, pregunțándose “ ¿en qué consisten los mitos de una sociedad?" Respondiendo:

"Ellos forman el discurso de esta sociedad y un discurso para el cual no hay emisor personal; por consiguiente un discurso que se recoge como un lingüista que se va a estudiar una lengua mal conocida y de la cual trata de hacer la gramática sin preocuparse de saber quién ha dicho lo que ha sido dicho" (Lévi-Strauss et al. 1967: 170).

Bien, a mí me preocupa quién ha dicho el mito, cómo lo ha dicho, y en qué circunstancias lo ha dicho, puesto que en la situación de narración, en la posición del narrador y en su interpretación descubriré énfasis particulares, asociaciones, y entonces formas de historicidad que están en la versión particular, como también la afectividad y los sentimientos, expresados por el narrador. Estos sentimientos permiten entender muchos sentidos del mito, y en nuestro caso, veremos que el conjunto de relatos que constituyen El Familiar tiene un sentido de provocar terror, de actualizar en la memoria dicho terror y de fetichizar relaciones sociales particulares.

Por fin, quisiera esbozar un último comentario crítico al método de Lévi-Strauss, con todo el respeto que me merece su abundante y calificada obra. El reconoce buscar materiales míticos que puedan ser interpretados según su modelo esbozado, dejando para otra oportunidad aquellos que presentan con- 
tradicciones, falacias etc., con relación al modelo privilegiado. En este sentido, considero que las versiones más contradictorias y adversas a la explicación deben ser incorporadas en el corpus, pues, en definitiva, es en la heterogeneidad de versiones e interpretaciones donde deben encontrarse los sentidos que, especialmente en el caso de las sociedades complejas, son variados y prolíficos. El mensaje mítico está muy relacionado a la agencia del emisor, por lo que me interesa ubicarlo en el contexto histórico-social del mismo, que resalta en cada versión. Si se quita el mensaje, si éste no es descifrado y analizado, se quita justamente la historicidad del mito. Así estoy más cerca de Hill (1988) cuando sostiene que las sociedades indígenas luchan por darle un sentido a la historia, además de aprehenderla. Pero los mitos no sólo tienen un contenido histórico (en nuestro caso: la celebración del Pacto, como origen del Ingenio, la Plantación y por tanto la Riqueza) o un mensaje profético sobre el porvenir (que, en nuestro caso augura, nuevas desapariciones), sino también tiene una relación sobre el presente (en nuestro caso el efecto de disciplinamiento por medio del terror).

El estructuralismo pensaba al mito como ficciones y la historia como hechos. En realidad ambos son textos y modos de conciencia social, constituyendo marcos interpretativos. Por ello, mito e historia no pueden separarse o distinguirse fenoménicamente, sino analíticamente como modos de conciencia social de formas complementarias de interpretar los procesos sociales.

A diferencia de lo que se hace habitualmente en los procedimientos expositivos con los relatos míticos, leyendas o cuentos, presentaré a lo largo de estas páginas dos versiones ${ }^{9}$, en el contexto del curso de entrevista. En general, la presentación de este tipo de relatos es transcrita en las obras finales como un relato terminado con principio y fin. Por lo que es una reconstrucción expost, hecha por el autor. Sin embargo, a lo largo del trabajo de campo, el relato es recogido en una conversación, donde aparecen digresiones, énfasis, sinécdoques, reiteraciones e interpretaciones del mismo actor. En otra parte (Isla y Taylor 1995) hemos presentado la versión separada del texto de la entrevista, por lo que muchos aspec-

9 Las comparo en el artículo con otras de fuentes secundarias. 10 La acepción número 15 de "familiar" en el Diccionario de la Academia (Real Academia 1992) dice: "Demonio que se supone que tiene trato con una persona, y a la que acompaña y sirve". Sobre la misma palabra otro diccionario dice que tos destacados en el relato son producto del autor y, en menor medida, del entrevistado.

Como dice Bourdieu (1993: 916), en una entrevista así expuesta podremos

"comprender no sólo la lectura del análisis de la conversación de cada discurso en términos de estructura específica de interacción como una transacción, sino también en términos de la estructura invisible que la organiza".

También Bourdieu afirma la existencia de problemas en la transcripción de la entrevista; o sea en la escritura, pues además de los posibles cambios de sentido, por una coma, o un punto, el autor puede estar por ejemplo "afirmando un consenso moral en la reafirmación de valores comunes" (Bourdieu 1993: 923). También agregaría el peligro opuesto de exotización; o sea, reafirmar determinados valores recortados del contexto y extrapolados artificialmente de los propios del autor. La vigilancia sobre el punto de vista del actor debe ser extrema, coincidiendo con Bourdieu en la propuesta de "democratización de la postura hermeneútica" al presentar la materia prima del análisis.

Pero además uno debe tener una actitud "democrática" con el corpus para vigilar los puntos de vista; o sea, incluir puntos de vista diferentes, distantes de aquellos que se fundamentan como centrales en la elección de las versiones.

\section{La producción social de terror en el ingenio}

En el paisaje político de los amplios territorios azucareros y entre los sectores populares deambulan monstruos míticos, que actúan sobre las prácticas culturales cotidianas tanto en períodos democráticos como durante las dictaduras. Estos seres representan relaciones sociales y simbólicas en la producción, entre el trabajador y su empleo, el lucro y la industria, el obrero y su patrón; al hombre con sus gremios y sindicatos, bajo gobiernos y otras instituciones estatales.

De esos engendros demoníacos algunas versiones seleccionan y juntan a dos de ellos: al Familiar ${ }^{10}$ y al Lobisón ${ }^{11}$, y al hacerlo, resaltan la aparente para-

entre los siglos XVII al XIX se podía entender como el "demonio que se supone tener trato con una persona y acompañarla y servirla" (Alonso 1982).

11 La presencia del Lobisón en las leyendas parecería de menor importancia que la del Familiar. 
doja de un pueblo contestatario y participativo, a la vez que pasivo y autoritario. Pero además, denuncian la importancia de estas creencias en el imaginario obrero, y las maneras de resistir o mitigar sus efectos hablando del terror.

Así me narró la "superstición" del Perro Familiar Juan Ignacio Tapia, dirigente sindical en Tafí Viejo, con una larga trayectoria política como activista y militante obrero:

Tapia: "La gente grande de aquí, en especial los anarquistas, ellos tenían una publicación que se llamaba la "Revista Blanca". En esa revista ellos denunciaban la existencia del Perro El Familiar, que había sido creado por Alfredo Guzmán, que había sido senador como 60 años.

Isla: ¿Senador de Tucumán?

Tapia: Sí. Era un filántropo. Era dueño de varios ingenios. Por Clodomiro Hileret, que era otro dueño de ingenio ${ }^{12}$, y otro Martín Vero, otro dueño del ingenio. Ellos, por ejemplo, en todos los fondos que tenían ellos de caña, en noche de plenilunio, salía un perro a recorrer la estancia y siempre había una víctima; desaparecía un hombre o lo mataba a un hombre. Resulta que había hombres muy valientes que se deciden a descubrir eso, y lo esperan al perro en noche de plenilunio, al Perro El Familiar; y lo enfrentan. $Y$ al hombre ese se sabe que pelea, pero al otro día el hombre no aparece, ni aparece el perro. Y ese misterio se ahonda, porque entra a tener miedo la gente. Ha desaparecido el hombre tal, y el perro no aparece. En esa zona donde ellos han peleado está lleno de sangre del perro y del hombre.

Isla: Y no aparecía ninguno de los dos.

Tapia: Pero resulta que después de eso, había un hombre más valiente y hacen: se ponen con dos... hacen la guardia; y ven cómo los tipos que lo enfrentan al perro desaparecen. Por lo visto son testigos de que no desaparecen porque el perro los come, sino porque el perro era cuidado por una banda de delincuentes, que andaban para atrás del perro, que eran pagados por los patrones para meter miedo a la gente. Si alguien le hacía al perro algo, el grupo ese lo levantaba a ese que lo enfrentaba y lo levantaba al perro muerto; le pegaban balazos con escopeta, o a otro lo han apuñalado. Pero después no han aparecido ninguno de los dos. ${ }^{13}$

Bueno pero después los anarquistas cuentan de que no era tan así; de que no había ningún misterio, ni era el diablo, sino que era una cosa creada por los hombres estos: seres humanos, Alfredo Guzmán, Clodomiro Hileret y el otro Martín Vero.

Isla: ¿No te acordás dueños de qué ingenios eran?

Tapia: Alfredo Guzmán era dueño del Ingenio Concepción, actualmente son los Paz herederos de él y Clodomiro Hileret...

Isla: Ah. ¿los Paz son herederos?

Tapia: Claro, herederos del Dr. Guzmán, y los de la Granja Modelo Viaña también porque ellos no han teníu hijus, iban quedando en la Sala Cuna de Tucumán, pero para tapar las cosas de las hijas de la sociedad, la sociedad. Como entonces no había anticonceptivos, nada, lo metían en la Sala Cuna a los chiquitos, los dejaban ahí. La piba salía como que había estado en Norteamérica, o Buenos Aires y seguía siendo señorita. $Y$ después este Alfredo Guzmán los recogía y los cuidaba como si fueran hijos de él; los reconocía o les daba el apellido así, cosa que sea el heredero d'él, porque no tenía hijo.

Isla: $A h$ ¿Por eso decís que era un filántropo?

Tapia: Sí, y era un tipo que ayudaba a la institución esa; a la gente del campo estaba por explotar, y bueno lo mismo hacía Patrón Costa en Salta; y otro tipo que tenía el obraje grande en Salta también hacía lo mismo. Bueno, la cosa es que en el año 1900, 1890, se hace pesao el crimen en Tucumán porque había masacre de gente; no víctima del $\mathrm{Pe}$ rro El Familiar, sino porque les decían que lo mataran al Perro El Familiar. Porque instigaban a la gente a que él tenía varios hijos, el séptimo hijo varón era el Diablo, era el Lobisón, decían. De noche de plenilunio venía y se transforma en diablo. Y ése comía gente; hace desaparecer. Pero no era así; sino lo que cuentan los anarquistas. La cosa es que Saénz Peña, siendo diputado de la Nación y su padre Presidente, Luís Saénz Peña; el hijo se llamaba Roque; éste juna el asunto y presenta un

12 Del ingenio Santa Ana.

13 O sea, ninguno de los dos valientes que lo enfrentaron. 
proyecto a la Cámara de Diputados, y nadie le da pelota. Pero cuando es Presidente él hace la ley Saénz Peña del Voto Universal y secreto, y al mismo tiempo hace la ley de "padrinazgo presidencial" porque él veía que en Tucumán era muy grande la creencia de que el diablo existía, y que el séptimo hijo varón es el hijo diablo; y hace la ley para que el séptimo hijo varón sea bautizado, en un bautizo público y que el padrino de ese chico sea el Presidente de la Nación, sea representado o por presencia de él. ${ }^{14} Y$ él, por eso, cuando él es Presidente, todos los años viene a Tucumán hasta que se muere; está cuatro años y muere...

\section{Isla: ¿Era tucumano Saénz Peña?}

Tapia: No, era de Buenos Aires; pero ... el vicepresidente de Saénz Peña era Victorino de La Plaza que era de Salta. A lo dos años ya entra Yrigoyen porque él es el que levanta la proscripción del Radicalismo incluso. Y el Dr. Luis Roque Saénz Peña, él viene a Tucumán cuatro veces cuando es Presidente y era un hombre partidario de todas las causas populares. Cuando es la guerra en el Pacífico, de Chile contra Bolivia y Perú, él va voluntario en el ejército peruano, pierde la guerra y después viene para acá. Después lo condecora el gobierno peruano, porque él defiende; tenía el grado de capitán en el ejército. Roque Saénz Peña va y hace partido presidencial porque cuando había un caso de esos que desaparecia un hombre, los patrones y los capataces de los ingenios instigaban a la gente de que habia que meterle fuego al viejo tal o cual, porque tenía siete hijos, el séptimo hijo ese era Lobisón. $^{15}$

Isla: Y ahí aparecía el Perro Familiar.

Tapia: No, no, no!

Isla: ¿Eran dos cosas distintas?

Tapia: No, era lo mismo; nada más que como aparecia el Perro Familiar, ellos dicen que el que se transformaba en Perro Familiar era el séptimo hijo

14 En realidad el "padrinazgo presidencial" como institución jurídica fue creado recién en 1973 por un decreto presidencial $\left(\mathrm{N}^{\mathrm{a}} 848\right)$. En los fundamentos se señala que la primera vez que se aplicó fue en el año 1907, siendo presidente de la Nación José Figueroa Alcorta, "Que desde entonces, invariablemente, todos los primeros magistrados otorgaron el padrinazgo, a pedido de parte, hasta convertirse este acto en costumbre tradicional" ADLA - XXXIV-A, pp. 251. varón. Pero el que por ahí tenía siete hijos, por más cobarde que seas vos, vos sos valiente porque tenés siete hijos para tirarle la bronca a cualquiera; te van a defender; el que no tiene ningún hijo varón no tiene como darle al dueño porque está solo, entendés. O sea que la mayoría de los hombres que tenían siete hijos no se dejaban avasallar sus derechos en el ingenio, que les paguen lo que se les baje la gana. Ellos armaban lío; ellos nomás iban del patrón y qué se le pague tanto; pedían o exigían al patrón, estaban los hijos con ellos, con puñal en lat mano.

No, el asunto del Perro Familiar es así: dice que como éstos andan en todo el mundo, va a ver que nosotros los trabajadores no los conocimos a los dirigentes ni de Bolivia ni del Paraguay; pero ellos sí, los patrones se conocen los de Rusia, de Norteamérica, del Japón de todos lados; ellos tenían acuerdo con los zares de Rusia, la familia de Romanov de Rusia; ellos traen perros grandes, galgo ruso, negro, o si no los teñian de negro; los largaban de noche con una larga cadena; como eran perros muy grandes, los otros perritos aullaban. En las noches de plenilunio, los perros siempre le aúllan a la luna, y más cuando ven a un animal enorme como éstos, semejante!, que parecía un toro, los perros un griterío bárbaro; los perritos iban a enfrentar y éstos los mataban; o los matones que iban por detrás lo mataban a los perros y después decían que los perros habían muerto. La cosa es que era así... y bueno la cosa era así. Por eso él rompe con esa creencia, pero hay gente que cree lo mismo de que el diablo no era el séptimo hijo varón sino que ésa era una versión tendenciosa para que lo liquide a esa familia numerosa de varios hijos varones, para que no haya escollos en los caminos de los patrones. Que sigan cometiendo las iniquidades que ellos quieren. O sea que esa es la leyenda del Perro Familiar. Saénz Peña va y muere en 1912, creo que muere por ahí. Ha quedado la ley de ahi. Y cuando Isabel es Presidente ella la amplía la ley, ya no únicamente siete hijos varones, ya ahi siete hijos sea varón o mujer ahi está el Presidente. Lo apadrina; porque ella es la primer Presidente constitucional. Ella es así, ella bautiza varias mujeres

15 La conversión del hombre en lobo las noches de plenilunio, o licantropismo. tiene raices históricas muy prolundas en los paises europeos centrales (Oates 1989, para el sur de Alemania y Francia) y mediterráneos. También se pueden dar transformaciones humana en "tigre" o "runa uturunco" (por ejemplo, la versión de Cejas 1995). 
que son la séptima hija mujer. Ella la amplía la ley.16 Incluso la Isabel ella la amplía la ley, porque ella hace de eso dice "Está bien", dice. "Le damos la cristiandad, pero qué hace con tener una medalla de oro", dice, "provista por el Presidente, si no tiene trabajo". "Darle preferentemente trabajo y a la madre premiarle con una pensión vitalicia, con el sueldo mínimo, vital, móvil". Ella a todas las mujeres que tienen siete hijos, le corresponde una pensión vitalicia.

Isla: Volviendo a lo del Perro Familiar, ¿eso se siguió manteniendo prácticamente hasta ahora?

Tapia: Claro, eso se cree todavía hasta este momento; por eso habrá vivos que todavía lo usan, "parece que yo lo he visto", te dicen.

Isla: Ah, ¿te dicen?

Tapia: Sí te dicen, claro.

Isla: Pero, ¿gente del campo o de la ciudad?

Tapia: No, del campo. Dicen "Yo lo he visto, tal...". El viejo Zenón: ¿te acordás? él decía que él lo había visto.

\section{Isla: ¿En qué circunstancias?}

Tapia: El decía que ahí en Famaillá, en las quintas. Dice que él lo había visto al Perro Familiar; estaban en una huelga y lo ha visto y han disparao todos los otros. Y bueno quizá el miedo lo hace ver a otro. Yo no veo; cuando tienen miedo ya lo ven todos. Entonces Bárcenas, también él decía que lo había visto. El era loco, pobrecito. Es ese el asunto.

Isla: Habría que ver si no hay algunos relatos de gente de ahora, ¿no?; de gente actual. Que lo haya visto ahora. Capaz que el Punta conoce a alguien.

Tapia: Claro, ahi en esa zona es donde aparecía. Tiene que haber viejos que pueden...

Isla: Pero no solamente viejos, gente joven porque parecía que dentro de la familia habia... pesaba tanto el Perro, que los mismos padres le decian al hijo

16 Hay versiones en Jujuy donde la séptima hija mujer es lobisona o en otras provincias es bruja. Comunicación personal de Elena Bossi. cuando se portaba mal: "Te va a agarrar el perro".

Tapia: ¡Si!

Isla: ¿Vos no ves alguna asociación entre el Perro Familiar que hacia desaparecer gente y los militares en el '70?

Tapia: $Y$ bueno, casualmente, los perros ${ }^{17}$, yo le he leído ése la Estrella Roja', ellos decian "la Triple A es el Perro Familiar de los '70". Los perros decian asi que los encapuchados eran los perros familiares de los '70. Como ya la gente, la mayoría no le creía al Perro, directamente lo reemplaza por los encapuchados. Que antes también era nada más que la pantalla, era como que el perro que mataba, ahora son los hombres que se hacen cargo". (Entrevista de diciembre de 1993).

En la compleja versión de Tapia a lo largo de la entrevista --una metaversión que permitirá abrir varios y sucesivos contextos-- resalta en primer lugar la experiencia social de quien la cuenta. En este caso, es la interpretación de un militante obrero; se trata permanentemente de denunciar el sentido ficticio que tenía el mito, escondiendo las verdaderas masacres encargadas por la patronal para disciplinar a los obreros. Su interpretación está relacionada al control de la lucha de clases en primer lugar; sembrar el terror para disuadir al activismo, a la militancia y en especial a las bases obreras, en sus intentos de reclamos salariales, mejoras laborales o la posibilidad de sindicalización. Toda protesta o incluso reclamo obrero se respondió casi siempre con violentas represiones que pretendían un carácter pedagógico, y esto no fue ficción. Las primeras agrupaciones anarquistas trataban de disuadir las creencias en el Diablo, entregando su prensa --producida con medios precarios-- mano en mano en la fábrica, como en los surcos de la plantación. Ellos eran obreros también y de noche cuando podían, en reuniones en las colonias intentaban 'desenmascarar' al Perro; detrás estaba la patronal, o los capataces, o matones contratados, cuando la agitación social se hacía densa. Pero tuvieron escaso éxito con su prédica a principios del siglo XX.

En la interpretación de Tapia, el mito es una "superstición" inventada por la patronal, pero recono-

17 Forma popular de llamar a los miembros del PRT (véase nota 7).

18 Organo de prensa del PRT-ERP. 
ce la fuerza (la eficacia simbólica) que tenía este relato entre las "gentes". Incluso marca su génesis, generando una nueva versión: gracias a sus relaciones internacionales ${ }^{19}$, los grandes patrones de los ingenios tucumanos, logran traer a fines del siglo XIX, principios del XX, "galgos rusos" cedidos por "los zares", que, para su uso como Familiar, podían ser "teñidos de negro". El negro es un color importante, que se repite en la mayoría de las versiones. Tapia denuncia el carácter patronal del mito, pero a fuerza de inventar otro. Así, las versiones se complementan, se refuerzan, se enriquecen a veces contradiciéndose.

Los ingenios constituyeron una experiencia dramática y ambigua, siempre relacionada al terror, pero también al conchavo y al dinero, para los trabajadores permanentes o transitorios. De acuerdo a sus diferentes tradiciones culturales representaban y transmitían esa experiencia de muerte. Por ejemplo, los toba del Pilcomayo asociaban la muerte por las enfermedades y las pestes en la zona caliente de la selva de la cuenca del río San Francisco, Jujuy, a los payaq (demonios), quienes bajaban de los cerros de Calilegua, en los bordes de las tierras del Ingenio Ledesma, y asolaban sus campamentos cuando iban a la zafra. Además describen grupos de comedores de carne humana, los kiyagaipí, quienes a veces trabajaban en los ingenios y conchababan indios a quienes pagaban con restos humanos (Gordillo 1997). También entre las múltiples asociaciones simbólicas del Familiar entre los toba está "la Gendarmería" y la "Policía", fuerzas que tienen presencia permanente en los Ingenios, como en las grandes minas de la región (Gordillo 1997).

\section{EI diablo en otros parajes}

Los cañaverales del Noroeste argentino no son el único lugar del mundo donde semejantes seres amedrentan y estimulan la imaginación obrera. Los trabajadores de latifundios ganaderos del sur de Nicaragua y del norte de Costa Rica, como aquellos empleados en la industria azucarera del Cauca (Colombia) hablan de pactos con el diablo para incrementar la riqueza.

Semejanzas entre los pactos colombianos de un lado y las creencias de los mineros bolivianos, han sido destacadas por el antropólogo Michael Taussig (1980), basándose en su trabajo y en el de June Nash (1979):
"En dos distantes vastas áreas rurales de Sud América, cuando campesinos cultivadores se transforman en trabajadores asalariados sin tierra, invocan al demonio como parte constitutiva del proceso de mantener o incrementar la producción... El Demonio y el mal condimentan la metafísica del modo de producción capitalista en estas dos regiones.

Entre los desplazados campesinos afrolatinoamericanos, quienes son empleados como trabajadores asalariados por la rápida expansión de las plantaciones de caña de azúcar... en el... Valle de Cauca en Colombia, son sólo algunos quienes... entran en los pactos secretos con el demonio para lograr incrementar su producción y de esa forma su salario. Cada pacto es mencionado como teniendo funestas consecuencias para el capital y para la vida humana... la tierra se volverá estéril, y los animales no procrearán y morirán. Así mismo. la... caña de azúcar se tornará infecunda... también es mencionado... que el individuo que hace el pacto... morirá prematuramente y con sufrimientos...

Similarmente, los indios desplazados como campesinos quienes trabajan como asalariados en las minas de estaño [de Bolivia] ... han creado grupos que profesan rituales al demonio... lo mismo que en las plantaciones colombianas de azúcar, el demonio es el mayor sostén de la producción o del incremento de la misma; pero esta producción es considerada a la larga destructiva de la vida...; la militancia política y la conciencia radicalizada de izquierda son muy altas en ambas áreas de estas industrias" (Taussig 1980: 13-14 y 144).

Impactan tanto las semejanzas como las diferencias de los lazos entre el diablo y la riqueza generada por la industria en países distantes. Entre los trabajadores azucareros con los que habló Taussig, el peligro de los pactos con el diablo se daba solamente entre los obreros, mientras que los dueños quedan inmunes (Taussig 1980: 110). En la industria azucarera argentina, como en las explotaciones ganaderas de Nicaragua y Costa Rica (Edelman 1994: 62), generalmente los pactos no son celebrados por los trabajadores, sino por los propietarios de las em-

\footnotetext{
19 Valentié menciona un relato que indica que el mito fue traido de Francia por Clodomiro Hileret, "inspirándose en el sabueso de los Baskerville y utilizándola en provecho personal" (1973: 36).
} 
presas, cuyas fortunas pueden gozar de incrementos estrepitosos o esfumarse vertiginosamente, de la misma manera que sufren los peones colombianos del azúcar.

Sin embargo Whiteford (1981: 55 y Nota 7, 162) encontró que las familias de trabajadores migrantes bolivianos en Ledesma --el ingenio más grande de la Argentina-- hacían pactos con el Diablo de manera idéntica a lo que encontraba Taussig en Colombia. O sea, para incrementar su productividad en el corte y pelado de caña, negociaban su alma o la de sus hijos (que por ello algunos morían) con el Diablo. Son los riesgos que se corren para alcanzar la riqueza o por ambicionarla. Pero también esos mismos trabajadores estacionales, atribuían la riqueza de las patronales a los mismos pactos.

La obra muy conocida y muy criticada de Taussig (Platt 1983, Dillon y Abercombrie 1988) propone una transformación de las imágenes de Dios y el Bien que tendrían los campesinos al integrarse al proletariado de la industria azucarera colombiana en expansión: dichas creencias mutan en el Diablo y el Mal. Esto es producto de su nuevo trabajo asalariado, cuyas relaciones son percibidas como extrañas y peligrosas, enajenantes y enajenadas. Este trabajo de Taussig, no obstante haber sido fuertemente cuestionado desde las más variadas perspectivas teóricas y disciplinarias, ha tenido sin embargo la virtud de instalar el tema de los pactos demoníacos dentro de un debate teórico fecundo, superando el estilo de las narrativas folklóricas, desprendidas de su contexto de relaciones sociales, económicas y políticas.

Es pertinente, no obstante, destacar algunas críticas. En las culturas andinas se han señalado la ambigüedad de sus dioses. Así el Diablo, o El Tío, o Supay es un personaje ligado al "mundo de abajo" (urkupacha), a lo tenebroso, pero también a la picardía, a la reproducción y fertilidad (por ejemplo, en los carnavales). En el contexto campesino de las zonas circundante ${ }^{20}$ a las cálidas azucareras, el diablo despierta las mismas ambigüedades. $Y$ aparece en otros relatos, de manera diferente; por ejemplo es bien conocida y extendida en la misma región la tradición de la Casa del Diablo o Salamanca ${ }^{21}$ : donde por las noches se escuchan los llamados tentadores e hipnóticos de hermosas mujeres que invitan a desprevenidos, seducidos o codiciosos a compartir los tesoros y los placeres, terminando frente al mis- mo Diablo quien los obliga al pacto, robándoles el alma. En las provincias del NOA son popularmente conocidos los lugares físicos donde hay Salamancas, y por eso no conviene dormir en las inmediaciones.

La presencia del Demonio en estas zonas de tradición campesina va más lejos en el tiempo como para caracterizarse sólo por ser el "condimento metafísico del capitalismo". En realidad, en la mirada del catolicismo popular el Diablo es "una metafísica de la riqueza" y esto es mucho más antiguo que el propio capitalismo; al Nuevo Mundo arribó no sólo la versión oficial bíblica de Lucifer, sino las que existían en los sectores populares de las culturas mediterráneas.

También Edelman (1994: 61) ha señalado que Taussig ha simplificado discursos y prácticas al atribuir homogeneidad al conjunto de campesinos que se proletarizaron en el Cauca. Siempre debería haber contradicciones, ambigüedades, fuertes contrastes entre las versiones cuando se toman varias; pero además Edelman señala la importancia de tomar aquellos relatos de personas que se refieren a estas creencias como "supersticiones". O sea voces, que como la de Tapia, desfechitizándolo, pretenden revelar los significados sociales por detrás del relato y lo contextualizan en la historia. En este caso el relato pierde fuerza mítica, pero cobra fuerza histórica.

Así las versiones argentinas resaltan, en las conversaciones y sentimientos cotidianos de los trabajadores en los ingenios, un peligro frecuente: la fuerte explotación y represión de la fuerza de trabajo. Las anuales "desapariciones" de vidas humanas eran atribuidas al "pago" o al compromiso del patrón con el diablo. Igualmente truculentas son algunas versiones de pactos en Centroamérica, donde el patrón ganadero transforma obreros en animales, que luego serán carneados para su venta (Edelman 1994: 62). La figura del Familiar evoca la explotación y represión de la fuerza trabajadora, así como el poder inefable de fuerzas ligadas a la familia del dueño de la industria.

20 En las punas jujeñas, salteñas y catamarqueñas, en los valles de las altas montañas, en las pampas de la provincia de Santiago del Estero y La Rioja.

21 Las salamancas eran "verdaderas academias, donde se doctoran brujas y brujos. Allí (el Diablo) asistido por dragones y serpientes... dicta su cátedra para reñir a Dios..." (Coluccio, 1963: 358). 


\section{Sacrificio y canibalismo}

En este punto, el mito del Familiar es una representación de la lucha de clases, pero también una teoría folk del capitalismo: la riqueza se produce y acumula únicamente mediante la extracción de sangre humana. La "desaparición" fue un método frecuente, pero numerosos testimonios de trabajadores, con sus cuerpos consumidos en las zafras de las plantaciones del norte (Salta y Jujuy) relatan su experiencia laboral en forma dramática: "he dejado mi cuerpo en el Ingenio". Los "cuerpos consumidos", la "sangre chupada" son expresiones que suelen escucharse entre los peladores de caña e indican las penosas jornadas en los surcos de la plantación.

Algunos autores coinciden con matices en esta interpretación del mito. Por ejemplo, Moise y Daino (1996) hablan de una "antropofagia ritual": el ingenio y sus dueños deben comer vidas humanas para que la producción funcione, fundamentado ello en una interpretación freudiana de las relaciones sociales de clase. El relato sería una "fantasía" obre$\mathrm{ra}^{22}$ compartida, a partir del poder y la imposición patronal. Siguiendo una línea interpretativa similar, se postula que el mito tenía "funciones catárticas" para los trabajadores en la medida que podía "expresar simbólicamente el canibalismo del patrón" (Montevechio, sin fecha: 108). Pero, en realidad, siempre este conjunto de narraciones transita por el ambiguo terreno entre ficción y denuncia. De esa tensión permanente resulta su fuerza. El Ingenio, para funcionar, debía devorar algunas vidas humanas por año.

Por otra parte, están amenazados no sólo peones individuales, sino la solidaridad obrera total, porque el Familiar ataca preferentemente a los obreros díscolos, según la mayoría de las versiones. Los obreros que reclaman son los preferidos del Familiar y entonces desalienta de forma simbólica --y a veces real-- la constitución de agrupaciones obreras, sembrando la incertidumbre entre los trabajadores estables y los temporarios, más proclives a ceder a los efectos de terror del relato.

Pero la voracidad del Diablo no se amortiguaba con los díscolos. Otras versiones recogidas en el campo y en las fuentes secundarias, mencionan que las víctimas son los "parias"; "esa gente que no tenía familia", con ellos se alimentaba el Familiar, y "por eso se movía el trapiche". Una ex-zafrera de varios ingenios de Jujuy y Salta, me contaba:

R: "Ah, sí! la gente boliviana es muy trabajadora, porque se ha criado sufriendo; trabajando uno sabe lo que, lo que es el trabajo. Yo por lo menos me he' $i$ criado en la zafra; yo he trabajado mucho en la zafra con mi papá. Yo cargaba. cargaba, macheteaba, a la par de un hombre yo sabía trabajar, asi que de eso...

P: ¿En Ledesma?

R: En Ledesma, en San Martín, en La Mendieta, he trabajado en zafra.

P: le voy hacer una pregunta, ya que usted ha trabajado en la zafra, aqui en Ledesma, porque algunos me han dicho que sí, y otros que no, ¿había Perro Familiar?

R: Ah! el que... sí, el Familiar sí; sí, con eso trabajaba él pue'... el capo de ahí.

P: ¿Qué?, ¿le tiraba el perro? (risas nerviosas).

R: No, no, ese el Familiar, ese humm... qué 'stá diciendo?, ese que se comía la gente, ¿o qué?

P: Sí.

$\mathrm{R}$ : Bueno con eso era... ocupaba años antes con esa gente que no tenía familia, ve?; no tenía hombre, o mujer o madre, nada de eso entonces, eso era la comida segura del Familiar; que se perdía de la noche a la mañana, quedaba la ropa no más.

\section{P: Nadie le reclamaba?}

$\mathrm{R}$ : Y claro, porque si no tenía familia, quién va a reclamar. La ropa nomás aparecía a la orilla de los cañaverales, o ahí en la orilla'l monte.

$\mathrm{P}$ ¿ ¿Y usted lo vio alguna vez?

R: No, no'i visto.

P: Pero hay gente que dice que lo ha visto, no?

R: Sí, sí, mi papá sabía contar: ahí la ropa del fula-

22 Aunque reconocen la existencia de hechos reales en la génesis del mito. 
no de tal y yai echaban ahi, y ya no estaba esa persona y sabían también. Todo trajina; salía en guacho, en perro, en cura, todo y así.

P: ¡Ah! ¿y en cura también salía?

R: Sí, en gallo...

P: O sea, entonces era el demonio?

R: Sí, sí, sí; trabajaba el ingenio con eso. Si no se comía gente no trabajaba; se paraba el trapiche; no molia; dice: se tenía que comer siempre.

P: ‘Qué bárbaro!, año a año, zafra a zafra, comia.

R: Sí, año a año tenía que comerse una persona, tres o cuatro personas; como ahí en San Martín ${ }^{23}$ había un montón de lotes, muchos a nombres de cristianos los lotes ${ }^{24} \ldots$ si muchos se querían ir y cada lote faltaban dos o tres personas.

\section{P: ¿Y estaban las cruces, así?}

R: Claro, las cruces y la ropa: ya la ropa lo echaban de menos para los semanales ${ }^{25}$; ya no sabian estar esas personas.

$\mathrm{P}:{ }_{\measuredangle} Y$ ni los huesos dejaba, todo, se lo comía entero?.

R: Todo hacía desaparecer; y eso sí es cierto, eso es cierto!!" 26

En esta versión la mujer destaca explícitamente la necesidad caníbal del ingenio; y la relación cotidiana con la amenaza de muerte y desaparición, mediante el nombre que le asignaban a los lotes: el de los desaparecidos de los años anteriores. Pero, además, la versión destaca que el tema de tener o no tener "familia" es fundamental en términos de las relaciones sociales en la perspectiva de los migrantes y trabajadores temporarios. En los lugares campesinos o rurales de origen de los temporarios, tener familia, haber constituido una, es símbolo de estatus de madurez de la persona en términos sociales y políticos, dado que el individuo demuestra su responsabilidad social. También es la familia --o parte de ella-- la que llega a la zafra y protege y controla afectivamente a sus miembros. La familia numerosa "da coraje", insinúa la versión de Tapia. Por último la "familia" ha sido convenientemente seña- lada como "el documento de los pobres". 27

Desde otra óptica teórica, que intenta explícitamente sintetizar el estructuralismo levistraussiano con algunas corrientes hermeneúticas, se sostiene que la idea de "sacrificio" es fundamental, pero que debe buscarse en las primeras versiones donde las víctimas humanas eran "inocentes". Y agrega la autora:

"por eso nos parece un intento de justificación y moralización tardios, el de las versiones en las cuales el Familiar devora a los obreros ladrones o perezosos. El castigo individual, e inclusive justificado de una falta individual, priva al mito de su dimensión social. Se trataría de un debilitamiento de su sentido originario; según el cual se trata de una comunidad en conflicto, que siente la amenaza de ser devorada por un sistema de producción que contradice sus creencias tradicionales... Interpretado asi el mito se nos aparece como la denuncia de una clase campesina desposeída y oprimida ante un sistema que considera injusto"28 (Valentié 1973a: 30$31)$.

Por el contrario el mito gana así una dimensión social permanente, al señalar y amenazar a los activistas y díscolos como víctimas o futuras víctimas. Entonces, no eran sólo los temporarios semicampesinos, sin familia. los devorados por el Familiar, sino también --aunque menos frecuente-- los obreros del ingenio, de tradición proletaria e iniciadores de agrupaciones y sindicatos. Por otra parte no se pierde la "dimensión social" con las versiones que denuncian castigos a "obreros ladrones y perezosos"-- como en la poesía de Piatelli que más ade-

23 San Martín del Tabacal, ingenio y plantación mayor de la provincia de Salta,de la familia Patrón Costa.

24 En los "lotes" vivían los temporarios durante la zafra. Los lotes llevaban los nombres de los desaparecidos o muertos atribuidos al Perro Familiar.

25 "Semanales" día del pago de todos los jornales u otras formas de pago en la semana.

26 Mi énfasis. Entrevista realizada en San Salvador de Jujuy (12/ 15/1993). A la fecha, la mujer tenía 56 años y se desempeñaba como vendedora ambulante de comidas.

27 Por la antropóloga Beatriz Heredia en su Comentario del artículo de Isla y Taylor (1995).

$28 \mathrm{Mi}$ énfasis. No hay una versión original, o un sentido originario en ningún mito; esto lo pone el autor desde su interpretación. Parto de la base que es imposible y estéril responder a la pregunta por la versión original. Por otra parte, al atribuir a mito el carácter de "denuncia de una clase campesina desposeída" la autora anticipaba la polémica interpretación de Taussig. 
lante transcribo. ${ }^{29}$ Estas prácticas sabemos, son formas espontáneas, fragmentarias de resistencia frente a la patronal, o frente al poder.

\section{Disciplinamiento y memoria}

El Familiar está inscrito en la memoria obrera bajo el terror, produciendo un efecto de disciplinamiento; éste no sólo afectó las prácticas explícitamente políticas (como los diferentes tipos de protesta obrera colectiva), sino también las cotidianas en relación al trabajo y al ocio los "transnochadores"...después del alcohol y el juego".

"Un aullido agudo y largo

Rompe la noche por miedo

Las casas trancan sus puertas

$Y$ se murmuran los rezos

Los rezagados se apuran

El Familiar anda suelto

Se dice que el Familiar

Es el demonio hecho perro

$Y$ que tiene sociedad

con el dueño del Ingenio

Por eso anda persiguiendo

a los borrachos y el juego.

Ninguno vio al Familiar

Porque el que lo vio está muerto

Pero dicen de su boca

Que va despidiendo fuego

Por eso sus muertos tienen

quemaduras en el pecho

Algunos no aparecían

Ni los rastros de sus cuerpos

Los ponían en el engranaje

Que iba moviendo el Ingenio

Porque así, según decian

Aumentaba el rendimiento

Van pasando muchos años

Años que forman los tiempos

y se seguirá contando

como real o como cuento

la historia del Familiar

que quedará como un sueño

$Y$ aquellos trasnochadores

Después del alcohol y el juego

Creerán sentir por las noches

tambaleando en los senderos

Un aullido agudo y largo

Como un eco del Infierno."

Juan Eduardo Piatelli (sin publicar)
Contrariamente a la interpretación de Valentié (1973a), diría que la desaparición simbólica de obreros reclamadores e indisciplinados, representa a menudo desapariciones reales, y entre ambas --simbólicas y reales-- refuerzan la dimensión social y dramática del mito: su efecto de terror. Tapia sin exponer una teoría sistemática denuncia las necesidades represivas de la patronal del ingenio.

Pero, además de obreros protestones, activistas, militantes, y parias, otras versiones insisten en categorías diferentes, como los "novatos":

"El del Familiar" era muy sonau hace muchos años, cuando recién hi caído por aquí. Resulta que los patrones del Ingenio para hacerse más ricos, habian teníu un contrato con el Familiar, que es el diablo, de darle cada año un pión pa' que lo coma. $Y$ dicen que lo cumplian y taban cada día más ricos. Todos los años dice que desaparecía un pión y nunca se sabia ánde se habia ido ni qué si había hecho. Ahi, en la fábrica, dice que los gringos ${ }^{31}$ tenían un cuarto oculto con herramientas ande vivia el Familiar. Entonces mandaban a ese cuarto a un pión para que saque herramientas. Y siempre tenía que ser uno nuevo, que recién haiga veníu a estos trabajos. Dicen que el hombre dentraba y no salía más. ¿Quí habia síu? Que el familiar se lo comía" (Vidal de Battini 1980 vol. VIII: 803-804).

\section{De héroes y traiciones}

Sin embargo, no siempre el desenlace macabro de los relatos favorece a la patronal y al diablo. En algunas versiones aparece un obrero mítico, hombre, "varón, muy valiente", que lo vence, siguiendo recetas cristianas (p.e. Jabif 1983). El que se enfrenta al Familiar y lo vence, es casi un héroe mítico, pero no logra destruirlo. Luego de derrotarlo el héroe desaparece sin dejar rastros. Ninguna versión menciona su destino final; éste es incierto y oscuro, pero se va de la localidad donde se dio la pelea; nunca más vuelve, ni se lo menciona y el Familiar sigue en pie.

“En Tucumán también sostiénese que el Familiar es un perro grande que ronda los ingenios azucare-

29 Poeta popular tucumano que murió hacia 1965/70. El poema inédito me fue cedido gentilmente por el historiador y amigo Ramón Leoni Pinto.

30 Del Ingenio "La Esperanza", de la provincia de Jujuy.

31 La familia Leach, dueños de La Esperanza, era de origen inglés. 
ros cuidando los intereses de su amo con el cual tiene pacto. Vive en los sótanos del ingenio y su dueño, cada año, debe entregarle un ser humano como alimento. Si éste no cumple, peligra la estabilidad del establecimiento. Las rondas del Familiar son siempre nocturnas, pues se asegura que de dia permanece encadenado. El ser humano destinado al festín del perro, puede luchar con el mismo y vencerlo. Para ello debe emplear un "cuchillo sin pecar" 32 y obrar "en nombre de Dios" (Coluccio 1964: 155).

Valentié (1973: 32), siguiendo algunas versiones, ha interpretado que la aparición del héroe-obrero destruye al "monstruo, cesan los sacrificios humanos y la ruina cae sobre los que pactaron con el Diablo". Sin embargo, por otras versiones que ella misma cita, se colige que la ruina cae sobre todos: patrones que pactaron y obreros que eran sacrificados, puesto que el ingenio y la plantación mueren; es decir detienen su ciclo productivo.

La existencia de un héroe ha sugerido otras interpretaciones. Al vencer al Familiar y convertirlo en un perro inofensivo

"la imagen del peón se agiganta en su heroicidady virtudes y se produce asi la reversión originaria de la relación de poder.. Se podría decir que el mito favoreció la convivencia necesitada por todos para el enfrentamiento con una verdad dolorosa que llevaria al choque directo... el mito estaría al servicio de un equilibrio necesitado por la comunidad..." (Montevechio sin fecha: 108-109).

Sin embargo, por lo que sabemos, la historia de huelgas, tomas de ingenios, marchas y movilizaciones, acompañaron e impactaron el imaginario regional, como al mito. Los choques directos se produjeron como prácticas yuxtapuestas a las narraciones. Estas, con sus significaciones no "flotaron" caprichosamente; por el contrario se hicieron más o menos sangrientas de acuerdo a la coyuntura de la relación entre las clases.

Otras versiones narran que el héroe logra sacarle una fortuna al patrón. Este le paga para que desaparezca. Encontrarse con el Familiar tiene entonces dos desenlaces ineludibles: ser devorado (lo más frecuente), o vencerlo y desaparecer. Ambas alternativas aluden, de manera diferente, al peligro que amenaza al activismo obrero, tanto como a los trabajadores de base del azúcar: la represión o el so- borno. Por ejemplo, en una versión proveniente del ingenio La Florida, un obrero rudo es enviado a una pieza oscura para que deje sus herramientas y sea devorado por el Familiar:

"el hombre abrió la puerta y entró... se le arrojó encima un enorme perro negro con ojos brillantes. Con rapidez el hombre sacó un cuchillo y empezó a pelear furiosamente con el perro. Finalmente logró cortarle su oreja izquierda (allí se supone que el Familiar tiene su fuerza) ${ }^{33}$, derrotándolo...el hombre le dijo al administrador que denunciaria el hecho a la policía. El administrador le rogó que no lo hiciera y le dio mucho dinero para que guardara silencio. El obrero aceptó el dinero pero luego fue a la policía y denunció el acontecimiento" (Vessuri 1971: 62).

El obrero acepta el dinero, por lo que se enriquece repentinamente (iestamos en presencia de un nuevo pacto?), pero denuncia a la policía, que, en otras versiones, cuando en general es "abusiva" se la considera también como Familiar.

\section{El estupor frente al maquinismo y la moderni- dad}

Un numeroso grupo de autores interpretan al Familiar como un mito que se produce bajo el impacto de la modernización; los trapiches de acero, los hornos inmensos, las calderas permanentemente alimentadas, las poleas y engranajes, las centrífugas y demás maquinarias, produciendo un ensordecedor ruido, conmovieron la imaginación de campesinos que recién llegaban a la primera industria del país (Alvarez 1952, Colombres 1986, Barale 1990).

Colombres transcribe una versión del Familiar del Ingenio Santa Ana según la cual el día de la inauguración de las vías del tren que lo comunicaban a Río Chico, se echó en las vías e impidió su paso. El autor lo interpreta no como impidiendo el progreso según otras posturas, sino como que el Familiar está unido al progreso, o sea a la riqueza, al mercado (Colombres 1986).

Alvarez es más explícito:

"La fábrica azucarera trabajaba día y noche durante la zafra. Y la inexperiencia obrera y la impre-

32 Cuchillo que no se ha manchado con sangre cristiana. 33 Sólo encontrado en esta versión. 
visión patronal en muchos casos, provocaron periódicos accidentes; algunos de consecuencias fatales, como una caida en las fauces abiertas del trapiche o en los tanques de miel hirviendo... Estas desapariciones de las que no quedaba más que el último grito del desdichado, ahogado por el estruendo de las maquinarias engendraron en la mente popular el pavoroso mito" (Alvarez 1952).

\section{Las tentaciones del diablo}

Gramsci (1971: 1-51, 140) en diferentes tramos de su obra centró su atención sobre la relación entre sentido común y religiosidad popular, por cuanto comprobaba que esta religiosidad (particularmente católica en Italia) constituía el principal componente del sentido común de los sectores subalternos. El autor le confería al sentido común características peculiares en relación a gran parte de las tradiciones marxistas. Para él, los sectores populares pueden experimentar, probar, realizar prácticas no conscientes, pero que cuestionan por momentos, y con posibilidad creativa, el sentido predominante que la cultura hegemónica le imprime a los hechos. Esa religiosidad es una mezcla de creencias con significados morales, provenientes de diferentes épocas y tradiciones culturales; con reinterpretaciones individuales permeadas o permeables al momento histórico de las relaciones sociales del actor. Por ello, la multiplicidad de versiones y voces subalternas, que a veces pueden expresarse o hablar en su sí mismo, sin cambiar la posición de subalternidad. ${ }^{34}$ De allí que la presencia del diablo, y la plausibilidad de los pactos en todas las versiones nos sitúe frente a un horizonte cultural común a las diferentes tradiciones que confluyeron en la zafra de las plantaciones o en el trabajo en los mismos ingenios. Esta base de significaciones compartidas en el NOA, pero ampliamente esparcidas por toda América tiene, como tronco fundamental, un catolicismo de raíces coloniales. Dichas raíces no sólo hablan de una historia de 400 años de evangelización dispar pero pertinaz, sino que sus ecos en el mito rememoran relaciones sociales bajo la dominación colonial. El Diablo no aparece con la modernidad, o la industria azucarera a mediados del XIX; mucho antes de estos acontecimientos poblaba y colonizaba la imaginación de las diferentes culturas. Pero además. las relaciones sociales de producción en el azúcar tuvieron durante muchas décadas fuertes componentes coloniales; o sea, coacción violenta (p. e., el uso del látigo se prohibe formalmente en
1946) y carencia de salario dentro de las relaciones capitalistas. $^{35}$

En un trabajo etnográfico sobre moral y religiosidad popular en Antajé ${ }^{36}$ se sostiene que, siempre "para que alguien sea rico tiene que ahorrar y esconder dinero; si lo hace significa que tiene arreglos con el diablo" (Vessuri 1971: 59). La "avaricia", la "codicia" son pecados atribuidos a la influencia del demonio, y. por medio de ellos, se obtiene la riqueza mal habida; de allí que se requiera el pacto con él. Por eso la autora, siguiendo a Weber concluye sobre el mito del Familiar que "el contraste entre objetivos materiales (la riqueza) y objetivos ideales (la pureza) que es tan prominente en ciertos aspectos de la doctrina se expresa en la religión práctica de los antajeños como una oposición entre el rico avariento y el piadoso trabajador pobre que rechaza la ambición" ${ }^{37}$ (Vessuri 1971: 63). Interpretado así, el mito es despojado de sus efectos de terror, pues no se explica la necesidad social y simbólica de desaparición de vidas humanas entregadas al demonio; como tampoco se explica la identificación y/o sentimiento de envidia que produce la imagen del "rico, fuerte. valiente, muy hombre", en el "pobre, débil, cobarde, poco hombre" trabajador, que veremos enseguida. Hay que destacar que no en todas las versiones el trabajador pobre rechaza la ambición.

Pero también, esta idea que la "riqueza" la producía el Diablo estaba justamente relacionada con la producción repentina de riqueza sospechosa de ilegítima. La riqueza de las familias de la nobleza, era una riqueza de linaje y concedida por Dios. Pero también se pueden encontrar variantes de estas ideas

34 Frente a la pregunta desafiante de Spivak (1988) "Can the subaltern speak?", y a su compleja respuesta. me inclino a pensar que no todo es hegemonía o dominación o reproducción de habitus. Entiendo, como Ginzburg (1994) o De Certeau (1988), que personajes o porciones de sectores subaiternos pueden, en distintas coyunturas expresar posiciones en discursos verbales o prácticas independientes de la dominación y creativas.

35 En 1987 visité una localidad salteña, Santa Victoria Oeste, enclavada en las montañas. Comprobé que muchos arrendatarios del hacendado debian pagar sus deudas de almacén (boliche) yendo a la zafra del Ingenio San Martín del Tabacal. E1 boliche era de los mismos dueños de la tierra, quienes presentaban las libretas de deudas al ingenio, y éste les pagaba directamente, sin consultar con el trabajador. De todas formas. esto era una rémora excepcional del pasado para aquella época.

36 En La Banda, provincia de Santiago del Estero.

37 Los énfasis y los paréntesis son míos. 
en otros lugares evangelizados de América Latina. Por ejemplo, en un trabajo centrado en las relaciones de producción que se dan en la zona cafetalera de San Pablo (Brasil), con una buena etnografía sobre organización familiar, la gente sostiene que es Dios quien efectúa las desigualdades: "Dios produce los ricos y los pobres", dicen los trabajadores (Stolke 1988: 161).

La idea de concepción negativa de la riqueza, como parte de la moral católica también es mencionada por Valentié (1973a: 25), pero la autora advierte el peligro de una interpretación monolítica en este sentido y entonces escinde riqueza de poder: rechazan la riqueza, pero ambicionan el poder. Este, dice, adquiere un carácter más ambiguo desde la concepción de los sectores populares, citando la versión del peón de los Posse (Valentié 1973a: 26) y que reproduzco más adelante). Sin embargo la separación de esos dos atributos de la patronal es tan arbitraria como forzada.

Otra concomitancia de los pactos demoníacos, es que el Familiar se lleva el alma del patrón cuando éste muere. Una conocida zamba creada por José Moreno, con música de Valladares, alude a este compromiso final:

"Como se enluta la noche

y llora con las vidalas

porque en medio de los surcos

la muerte anda desvelada

De qué le vale al ingenio

tanto campo y tanta caña

¡Ay! del patrón cuando muera

p'al familiar será su alma

Ya viene la luna llena, madura la salamanca mientras llora la colonia por una boca de hilacha

Ojalá se vuelva azúcar ese negro lampalagua molido por el trapiche su sombra despedazada

Familiar yo soy zafrero sufrida grúa borracha

llevando vino a mis penas

cargadero de mi alma".
El pacto en muchas versiones concluye como en la zamba: cuando el patrón muere el Diablo se lleva el alma (Vessuri 1971: 60). Pero también existe la versión apoteósica del velorio de Clodomiro Hileret ${ }^{38}$ en los jardines exóticos que él mando a construir siguiendo las imágenes de un sueño de su hija. Donde se levantó su emporio azucarero, Santa Ana, se paseó en medio de una multitud de trabajadores y empleados un féretro vacío (Rosenzvaig et al. 1990: 76). A veces el Diablo también se lleva el cuerpo, y además dicen que terminado el pacto, se esfuma la riqueza del establecimiento, dejando en la miseria a la familia y linaje del propietario, como a sus trabajadores.

\section{Género y valores morales}

Pero en la versión de Tapia aparecen otros elementos fundamentales que es necesario enfatizar, para conformar una interpretación. La concepción de lo masculino y femenino, o sea las ideas de género, como las ambigüedades valorativas: "Guzmán era un filántropo", porque le daba el apellido a los hijos de las chicas "de la sociedad" que quedaban embarazadas. Parían en la Casa Cuna que él fundó "y salían señoritas"; justificando ellas y sus familiares que volvían de Buenos Aires o Francia. Pero Guzmán también tenía un Familiar en su Ingenio. En su figura se sintetizan los elementos centrales de relaciones de subordinación: la riqueza, el poder (fue senador), y el manejo y abundancia de mujeres; tanto en relación a su protección, como también a su poder prolífico de procreación.

El pacto es "cosa de hombres"; y el héroe, cuando lo hay, es siempre un hombre. Prácticamente no aparecen mujeres en la gran mayoría de las versiones. Esta predominancia masculina se multiplica con las ideas que rondan al Lobisón: ¿quién se le atreve a un padre con sus siete hijos varones?, parafraseando a Tapia.

Edelman (1994) en un brillante análisis sobre los "pactos con el demonio" en las zonas rurales del norte de Costa Rica y el sur de Nicaragua, ha relacionado su existencia no sólo con relaciones económicas de explotación, sino de poder en general que ejercen los grupos dominantes sobre los subordina-

38 Quien había fallecido durante una travesía marítima a Francia. 
dos. Una de las formas que destaca en su artículo es el abuso sexual "la coerción de favores sexuales", la "opresión sexual" como expresiones de ese poder (Edelman 1964: 60).

Una narración que considera al Familiar como una superstición que sólo puede creer la "gente pobre e ignorante", señala que "es preciso haber estado entre los pobladores que quedan en las inmediaciones del ex-Ingenio Santa Ana de Hileret ${ }^{39}$ para cerciorarse del pánico que se apodera de mucha pobre gente, especialmente de las mujeres, en las noches que se supone que el famoso can hace sus incursiones por el establecimiento" (Craviotto 1968). Ellas, en general no eran seleccionadas como alimento por el Demonio, pero el pánico se debía a la posibilidad de perder la familia de una manera horrenda, no cristiana, sin poder darles el debido velatorio y su sepultura para su descanso en paz. ${ }^{40}$

En relación al género y a la visión del ideal masculino, es interesante glosar una versión del Familiar publicada por uno de los descendientes del ingenio La Esperanza de Tucumán:

"Una de las creencias más difundidas en las regiones azucareras del país, es la del Familiar, embajador del demonio y guardián de los pactos que se celebran con él... la leyenda comenzó a tomar cuerpo entre los zafreros, a fines del siglo pasado, cuando los dueños de ingenios se enriquecieron rápidamente, gracias a esa fiebre del azúcar... la imaginación popular elaboró a su manera esas fortunas, producto de la revolución fabril operada por las grandes maquinarias. ${ }^{4 \prime}$ Las atribuyeron a secretos pactos que el patrón hacía con el Supay (el diablo) a quien entregaba algún peón a cambio de riqueza terrenal... de no cumplir el contrato debería entregar su alma... Por las noches atribulados trabajadores juraban haber visto ojos de fuego por el canaveral. La presencia arrastraba unas pesadas cadenas, además de despedir un fuerte olor a azufre, a su paso todos los perros callaban. La imagen...

39 Quien es considerado un procer de Tucumán.

40 Esta creencia cristiana se refuerza con las propias de las diferentes tradiciones culturales que, como la andina. considera a los "muertos" como seres con capacidad de presencia en ceremonias y acontecimientos de la vida cotidiana de los "vivos".

41 Otros autores también han sostenido que la irrupción de la modemidad en la región, con sus "grandes máquinas" impactó la imaginación popular, creando el mito el Perro (Colombres 1986). Sin embargo el azúcar hasta su crisis final que arranca más difundida entre nosotros le adjudica la forma de un enorme perro negro, de refulgente mirada y de largas uñas, capaz de desgarrar a un hombre con sólo un zarpazo, que se alimenta de carne humana..."42 (Posse 1993: 194).

Posse incluye a continuación el testimonio de un viejo peón de La Esperanza, Serapio Almaraz, que en 1971 aún vivía en la zona del ingenio, definitivamente cerrado en 1967:

"la riqueza de Esperanza dependía del Diablo: desde que el Esperanza fue paralizado... el Perro Familiar anda suelto, porque ya no tiene quién se haga cargo de él. Para este hombre, los Posse eran hombres bien puestos, no le tenían miedo, se le paraban delante y le hacian un contrato. Si yo fuera más joven, ahora que no están los Posse, le hubiera hecho frente. Algunos de los descendientes de don Wenceslao deberían venir y plantársele de frente: solamente asi volveria la riqueza al Esperanza. Todo depende de alguien que quiera ser socio con el Diablo, pero debe ser un hombre bien hombre" (Posse 1993: 195).

Serapio se identifica con los antiguos patrones. "si yo fuera más joven... podría ser como ellos", dice elípticamente. Expresa que "eran hombres bien puestos", y se "debe ser un hombre bien hombre" refiriéndose a una marcada masculinidad. En esa región, como en general en el lenguaje popular en Argentina, decir "los tiene bien puestos" se refiere directamente a los testículos. ${ }^{43}$ En la antigua zona del ingenio Santa Ana de Hileret, se recogió un testimonio similar: "si apareciera un hombre fuerte como Clodomiro, que se animara a plantársele al Diablo, Santa Ana volvería a resurgir" (Barale 1990: 70). Un hombre con semejantes atributos lograría un nuevo pacto; retornaría así la riqueza, el Ingenio volvería a producir y entonces a generar trabajo, uno de los elementos vitales de la crisis social tucumana desde mediados de los ' 60 .

a mediados de los '60 siempre constituyó una industria de mano de obra intensiva.

42 Mis énfasis.

43 "Es un hombre de huevos", o "se necesita un hombre con las pelotas bien puestas" se suele decir para referirse directamente a un hombre encarador, de autoridad, valiente. Muchas veces se dijo de Perón, pero también de muchos generales que vinieron después del '55. También se usaba en la militancia armada, para referirse a aquellos que "iban al frente". 
También en relación al héroe: quien triunfa sobre el Familiar, logra la fortuna, cambiar de naturaleza social, dejar de ser asalariado, obrero, pelador, y pobre para convertirse en rico. Hay que ser "muy hombre" o "muy macho" para lograrlo. Y esta versión cuasi patronal, se cruza con la obrera del Lobisón de Tapia: la patronal temblaba frente a la presencia de ocho varones que se le "animan" al patrón. El padre daba muestras de su masculinidad exacerbada: una prole abundante y además masculina.

\section{Luchas y complicidades de los subalternos. Al- gunas conclusiones}

Pero además de las relaciones directas con situaciones de explotación social, con frecuente coacción, con violencia física, y con la construcción de una masculinidad salvaje y prolífica, donde las mujeres quedan excluidas, "temerosas" de la lucha, los relatos también apuntan a identificar personajes como ejecutores de pactos que representan de alguna manera al Estado. Desde la experiencia y visión obrera, el Estado hasta 1944 jugó un rol inseparable de la patronal; de allí que prácticamente las versiones no diferencian los dueños de ingenios, con políticos encumbrados, comisarios de la policía, gendarmería y curas.

A su vez, los relatos de construcción originaria de la FOTIA (Federación Obrera Tucumana de la Industria Azucarera) muestran como los obreros fueron apoyados y se apoyaron en el nuevo Estado peronista para mitigar los efectos de dominación y explotación de las patronales. Con la FOTIA y su acumulación de poder, el Familiar desaparece por un tiempo de la escena tucumana. También relatos del Ingenio La Mendieta de Jujuy señalan que, entre 1946 y 1949, los obreros permanentes también habían logrado conformar un sindicato muy fuerte y que el "Familiar había abandonado los sótanos penumbrosos de la fábrica". Con la solidaridad obrera, y su representación sindical, el poder de terror del mito se desvanecía. En la versión de Tapia el peligro para la patronal era la posibilidad de enfrentarse con una familia extensa y enteramente masculina, acaso es el germen simbólico del sindicato, base de la solidaridad por la cual los obreros tantos años habían peleado.

José Moreno, autor de la zamba para el Familiar, envió en 1989 una carta al director de La Gaceta donde afirma que "[el] Familiar ya no espanta en el cañaveral tucumano desde hace 45 años cuando la FOTIA decretó su muerte, sindicalizando la peonada, porque según todos los indicios era un engendro patronal para escarmentar a los revoltosos" (Moreno 1989). Alvarez sostiene que la "leyenda pavorosa" del Familiar en el ingenio Ledesma $^{44}$ tendía a esfumarse a principios de los '50; las causas de su extinción, agrega, eran "la luz (electricidad) y el control de los hombres y no del diablo..que produjeron la escuela y las leyes sociales" del primer peronismo (Alvarez 1952).

Creo por último muy importante en la versión de Tapia, la relación con la historia. Con la historia del anarquismo en la región, pero también con la ley de padrinazgo del séptimo hijo varón destacada por Tapia; también la relación entre R. Saénz Peña y las causas populares. Más allá de coincidir o no con esta valoración sobre Saénz Peña, lo que me interesa destacar es cómo relatos fantásticos se entrelazan en su misma exposición, con acontecimientos inscritos en el terreno de la historia real. Esta combinación de historias de diferente género, de tiempos, espacios, seres míticos con personajes reales, es característica de la cultura popular.

Las diferentes versiones del Familiar tratan de explicar la riqueza y la desaparición de vidas de obre ros con la misma insistencia. La riqueza del patrón, abruptamente concebida en el imaginario popular, se debe al pacto demoníaco; la desaparición de personas, al alimento del Familiar, y por lo tanto máquina del pacto. En este aspecto, el mito opera como una gran metáfora de la succión de vidas obreras para engordar los tesoros patronales. Es necesario un acto de antropofagia para mover los trapiches; hay un imaginario de sacrificio y reciprocidad (exacerbada en sentimientos fatalistas) entre las clases; se debe poner el cuerpo y hasta la vida para que se genere la producción y la reproducción del orden social.

En la coproducción de los sentimientos de sacrificio juegan varias concepciones del mismo, que confluyen desde las diversas culturas en la región del azúcar. En las culturas andinas está cada vez más clara la idea de sacrificios humanos a los dioses, o a los poderes sobrenaturales, como una relación de reciprocidad tendiente a restablecer equilibrios entre el mundo de los vivos y el de los espíritus (Harvey

44 Según la versión que recoge, el Familiar en Ledesma era un viborón, otra forma frecuente de presentarse el diablo. 
1999). Estas nociones, a su vez, están empotradas en las ideas de sacrificio del catolicismo, con las imágenes de Cristo, mártires y santos, como ejemplos paradigmáticos.

Uno se debe preguntar el porqué de este tipo de pacto, en donde la patronal tiene que entregar anualmente vidas humanas para que el ingenio y la plantación funcionen; porqué la amenaza de muerte y terror debe aparecer mensualmente, en cada plenilunio sobre el conjunto de trabajadores. Porqué por fin, ese pacto no se celebró inicialmente y de manera definitiva, entregando vidas humanas, pero como festín inaugural. Mi respuesta a estas preguntas es que el tipo de relaciones sociales de producción, donde se combinan anualmente trabajadores temporarios (cuasi campesinos) con asalariados permanentes, requiere de formas de disciplinamiento constantes y especialmente de terror, ya que no se quería convertir a los campesinos en proletarios, sino mantenerlos en una producción asalariada de forma precaria. Las relaciones sociales están contextuando las narrativas sobre las consecuencias --canibalismo y sacrificio-- del pacto demoníaco.

Pero todas las versiones que yo he recogido o escuchado coinciden en que las personas son obreros o a veces animales; no he visto ninguna en donde se mencione al Familiar devorando administrativos o capataces del ingenio; o sea el mito tiene un claro sesgo clasista. De allí que el terror resplandece por momentos en la conciencia obrera, se hace presente en largos períodos, como la dictadura, o en determinadas coyunturas históricas. En esos momentos, el mito juega hegemónicamente para amortiguar o paralizar las luchas, para sembrar sospechas fragmentando lo social, en permanentes contra temporarios, argentinos contra bolivianos, coyas o vallistos contra los de las zonas bajas; al separar, aliena a los individuos. Pero la imaginación popular produce mezclas simbólicas y logra en el mismo relato invertir signos; aquéllos que producían muerte y desolación, pueden producir vida y riqueza.

Estas operaciones en el plano simbólico, muchas veces enfrentan confirmaciones históricas pavorosas o la imposición violenta y prolongada de valores y normas de vida, que transforman las relaciones sociales. Bajo estas situaciones los relatos tienden a destacar y rememorar efectos de terror; pueden augurar lo que vendrá.
En un artículo para el diario La Gaceta se concluía que

"el lenguaje de los mitos es siempre ambiguo, permite múltiples lecturas... el Familiar puede interpretarse como... un rechazo a la sociedad industrial y la añoranza de un pasado menos alienante, o por el contrario, en su expresión de futuro. como un fermento revolucionario que al denunciar la injusticia puede engendrar actitudes liberadoras. De todos modos la persistencia del mito, parece indicar que el Familiar anda suelto" (Valentié 1973b).

Sin embargo, la ambigüedad, expresada en la multiplicidad de sentidos, no es sólo patrimonio de los relatos míticos; es una forma de resistir o eludir el peso de la hegemonía o la dominación de los subalternos; de quienes no han construido una posición de poder; o que esa posición construida por décadas, como el caso de la FOTIA y sus cuerpos de delegados, fuera completamente aniquilada, como durante la última dictadura. El Familiar y sus relatos conexos nos hablan de muertes horribles y desapariciones ominosas, augurando siempre un uso futuro de la "desaparición" como instrumento político dentro de una tradición de represión.

Más que buscar por los orígenes europeos del mito, o atribuírselo directamente a la patronal, estoy proponiendo una coproducción del mismo entre las patronales, sus secuaces y los sectores populares. Pero en esta coproducción del mito juegan las relaciones de poder con sus asimetrías y jerarquías. El poder produce, ha insistido Foucault (1981). Las respuestas, la contestación al poder, también producen, estoy proponiendo; a veces de manera alienada, a veces desnudando las relaciones de poder; y entonces desfetichizan.

El Diablo, en este caso, juega como mediación simbólica, constituye una fetichización de las relaciones sociales: la patronal no se enriquece mediante la extracción del excedente, sino mediante el consumo de cuerpos y vidas. Es una teoría folk del capitalismo salvaje, como de la riqueza. El mito nos trae ecos de relaciones coloniales que aún subsisten o que amenazan reaparecer, de allí su carga de terror (Isla 1998: 148). Es un complejo sistema de representación, a través del cual se promueven normas y valores, articulándose lo público y lo privado, entonces el espacio social y la subjetividad. 


\section{BIBLIOGRAFIA}

ALONSO, M., 1982. Enciclopedia del idioma. Diccionario histórico y moderno de la Lengua Española (siglos XII al XX). Aguilar, Madrid.

ALVAREZ, R., 1952. El Familiar. La Prensa, Sección Segunda, 30 de nov. de 1952. Buenos Aires.

ANDERSEN, M., 1993. Dossier Secreto. El mito de la guerra sucia. Editorial Planeta, Buenos Aires.

BARALE, GRISELDA C., 1990. Santa Ana. Un modelo de cultura rural. Instituto Universitario de Artes PlásticasAguilares. Fac. de Artes UNT, Tucumán.

BOURDIEU, P., 1993. La misère du monde. Seuil, París.

CEJAS, O., 1995. El hombre Tigre o "runa-urturunco". La Gaceta 03/07/95, Tucumán.

COLOMBRES, A., 1986. Seres sobrenaturales de la cultura popular argentina. Biblioteca de Cultura Popular. Ediciones del Sol, Buenos Aires.

COLUCCIO, F., 1963. Dios, el Diablo y Judas en el folklore americano. Actas do $1^{\circ}$ Concresso de Etnografia e Folclore, pp. 63-87, Lisboa.

---- 1964. Diccionario folklorico argentino. Edición de Luis Lasserre, Buenos Aires.

CRAVIOTTO, T., 1968. Folklore tucumano. Leyendas lugareñas. La Gaceta. Tucumán.

DE CERTEAU, M., 1988. The practice of everyday life. University of California Press.

DILLON, M. y T. ABERCROMBIE, 1988. The destroying Christ: An aymara myth of conquest. En Rethinking History and myth. Indigenous south american perspectives on the past, J. Hill (Ed.) pp. 50-78, University of Illinois Press.

EDELMAN, M., 1994. Landlords and the Devil: Class, ethnic, and gender dimensions of central american peasant narratives. Cultural Anthropology 9(1), 58-93.

FOUCAULT, M., 1981. Vigilar y castigar. Nacimiento de la prisión. Siglo XXI, Madrid.

GETINO, O., 1972. El Familiar. Film.

GINZBURG, C., 1994. El queso y los gusanos. Muchnik Editores S.A., Barcelona.

GORDILLO, G., 1997 Ms. El aliento de los diablos: Una experiencia cultural de explotación y terror. Ponencia presentada al V Congreso Argentino de Antropología Social, 31 de agosto.

GRAMSCI, A., 1971. Il materialismo storico e la filosofia di Benedetto Croce. En Quaderni del carcere. Editori Riuniti. Italia.
HARVEY, P., 1999 Ms. El poder seductor de la violencia y de la desigualdad.

HILL, J., 1988. Introduction. Myth and History. En Rethinking History and myth. indigenous aouth american perspectives on the Past. University of Illinois Press.

ISLA, A., 1996. Hogar y Comunidad. Identidad y estructura social en los Valles Calchaquíes: El caso de Amaicha del Valle). Tesis de Doctorado presentada a la Universidad de Buenos Aires.

---- 1998. Terror, memory and responsibility in Argentina. Critique of Anthropology (18) 2: 134-156, Sage Publications, London.

ISLA, A. y J. TAYLOR, 1995. Transformaciones y fragmentación de las identidades bajo el terror en el Noroeste argentino. Revista Andina (13)2: 311-356, Cusco.

JABIF, N. L., 1983. El Familiar, ¿leyenda ofraude? Tiempo Argentino, 7/VLL/1983.

LA NACION, 16/7/1974.

LEVI-STRAUSS, C., P. RICOEUR P. y E. PACI, 1967. Problemas del estructuralismo. Editorial Universitaria de Córdoba, Córdoba.

LOPEZ CANTOS, A., 1992. Juegos, fiestas y diversiones en la América española. Editorial Mapfre, Madrid.

MAHIEU,A., 1975. Leyenda y teoría en "El Familiar" de Octavio Getino. La Opinión, 10/10/75, Buenos Aires.

MOISE DE BORONIA, C. y L. DAINO, 1996. El familiar: Una antropofagia social. Simposio Internacional de Mitos, Asociación Psicoanalítica Argentina, Buenos Aires.

MONTEVECHIO, B. R., Sin fecha. El Familiar. Un mito del norte argentino.

MORENO, J. A., 1989. Perro vampiro. La Gaceta, Cartas al Director, 6/8/1989, Tucumán.

MORENO, J. A. y R. VALLADARES, R., 1964. Zamba del Familiar. Editorial Lagos, Buenos Aires.

NASH, J., 1979. We eat the mines and the mines eat us. Dependency and exploitation in Bolivian tin mines. Columbia University Press, Nueva York.

OATES, C., 1989. Metamorphosis and lycanthropy in FrancheComté, 1521-1643. En Fragments for a History of the human Body, Part one, M. Feher (Ed.), New York.

PIATTELLI, J. E., Sin fecha. El Familiar. Poema.

PLATT, T., 1983. Conciencia andina y conciencia proletaria. Qhuyaruna y ayllu en el norte del Potosí. Revista Latinoamericana de Historia Económica y Social 2: 47-73, Lima. 
POSSE, J. M., 1993. Los Posse. El Espíritu de un clan. Editorial Sudamericana, Buenos Aires.

REAL ACADEMIA ESPAÑOLA, 1992. Diccionario de la Lengua Española. RAE, Madrid.

ROCA, M., 1972. Getino: ¿Quién es El familiar? Primera Plana $\mathrm{N}^{\circ}$ 488. 6/6/1972, Buenos Aires.

ROSENZVAIG. E., A. V. ROBLE y S.R. BLISS. 1990. El testimonio oral en el rompecabezas biográfico de las élites azucareras. Instituto Universitario de Artes Plásticas-Aguilares, pp. 74-80, Facultad de Artes UNT. Tucumán.

RUTLEDGE, 1., 1987. Cambio agrario e integración. El desarrollo del capitalismo en Jujuy: 1550-1960. Serie Antropología Social e Historia. Vol. 1. ECIRA-CICSO. S. M. de Tucumán.

SANCHEZ FERLOSIO, R., 1991. Esas Yndias equivocadas y malditas en 1492 - 1992. La interminable conquista. Emancipación e identidad de América Latina. Editorial El Duende, Quito.

SEOANE, M., 1992. Todo o nada. La historia secreta y la historia pública del jefe guerrillero Mario Roberto Santucho. Editorial Planeta, Buenos Aires

SPIVAK, G., 1988. Can the subaltern speak? En Marxism and Interpretation of Culture, C. Nelson y L. Grossberg (Eds.), Urbana, Illinois.

STOLKE, V., 1988. Cofee planters, workers and wives. Class conflict and gender relations on Sao Paulo plantations 1850 1980. St. Anthony's College Press. Oxford.

TAUSSIG. M., 1980. The Devil and commodity fetishism in South America. The University of Carolina Press.

VALENTIÉ. M. E., 1973a. El Familiar. En Ensayos y Estudios. Revista de Filosofía y Cultura $N^{\circ} 2$ y $3: 20-36$. San Miguel de Tucumán.

---- 1973b. Otra vez el Familiar. La Gacela, 7/10/1973, Tucumán.

VESSURI, H., 1971. Aspectos del catolicismo popular de San tiago del Estero: Ensayo en categorías sociales y morales. Revista América Latina (14) 1/2: 40-67. Río de Janeiro.

VIDAL DE BATTINI, B., 1980. Cuentos y leyendas populares de la Argentina. Ediciones Culturales Argentinas. (12 tomos), Buenos Aires.

W ACHTEL, N., 1976. Los Vencidos. Los indios del Perú frente a la conquista española (1530-1570). Alianza Universidad, Madrid

WHITEFORD, S., 1981. Workers fron the North. Plantations, bolivian labor, and the city in Northwest Argentina. University of Texas Press, Austin.

ZUIDEMA, T., 1980. Un viaje al encuentro de Dios: Narración e interpretación de una experiencia onírica en la comunidad de Chque-Huarkaya. En Reyes y guerreros. Ensayos de cultura andina, M. Burga (Comp.), pp. 33-53, Grandes Estudios Andinos. Lima. 
